\title{
TŁUMACZ JAKO AUTOR NA PODSTAWIE WYBRANYCH FRAGMENTÓW POWIEŚCI OLGI TOKARCZUK BIEGUNI
}

\begin{abstract}
Zarys treści: W ramach niniejszego artykułu przedstawiona została analiza działań translatorskich wynikających z przyjętej przez tłumaczkę autorskiej roli, której dostrzeżenie możliwe jest na przykładzie przekładu literackiego. Przedmiotem analizy jest tłumaczenie powieści Olgi Tokarczuk Bieguni. Można zauważyć, że autorskie działania tłumaczki ujawnią się przede wszystkim w zastosowanych przez nią technikach oraz strategiach translatorskich, które jednocześnie wpływają na stopień widoczności jej działań w przekładzie.
\end{abstract}

Słowa kluczowe: tłumacz, autor, rola autorska, modyfikacje, jawność tłumacza

\section{Wstęp}

Celem niniejszego tekstu jest ukazanie autorskiej roli tłumacza, którą przyjUmuje on w ramach tłumaczenia literackiego. Artykuł opiera się na analizie tłumaczenia na angielski wybranych fragmentów powieści Olgi Tokarczuk Bieguni w przekładzie Jennifer Croft. Książka ta, wydana w 2007 r., została uhonorowana nagrodami zarówno w Polsce, jak i na świecie. Kunszt literacki autorki oraz tłumaczki nagrodzono m.in. w 2018 r., kiedy to Bieguni jako pierwsza polska powieść została laureatem Międzynarodowej Nagrody Bookera (The Man Booker International Prize). Czytając dzieło, odbiorca poznaje historie wielu bohaterów, egzystujących nie tylko w znanej czytelnikowi rzeczywistości, lecz ma on również szansę na swoiste przeniesienie się w czasie i przestrzeni. Autorka prezentuje również swoje obserwacje odnoszące się 
do różnych dziedzin życia, często związanych z podróżowaniem lub egzystencją człowieka, które to motywy są głównym tematem powieści.

Niniejszy artykuł skupia się na działaniach twórczych tłumaczki w ramach zastosowanych strategii i technik translatorskich, a także ich wpływie na stopień jawności działań translatorskich w tekście docelowym. Analiza opiera się na następujących rozdziałach: Kunicki. Woda I, Kunicki. Woda II, Bieguni oraz Co mówiła zakutana biegunica. Wymienione rozdziały są wielowątkowymi, rozbudowanymi historiami, głęboko osadzonymi w słowiańskich realiach kulturowych. Dlatego też ich analiza translatorska pozwala na ukazanie zróżnicowanych działań autorskich tłumacza. Fragmenty omawiane $\mathrm{w}$ niniejszym artykule przedstawiają dwie historie. Pierwsza $\mathrm{z}$ nich przenosi czytelnika do Rosji, gdzie przedstawione zostają mu dwie postacie kobiece: Annuszki, opiekującej się chorym synem, oraz tajemniczej kobiety należącej do sekty Biegunów. Jedną z cech językowych tego fragmentu, która wynika $\mathrm{z}$ usytuowania jego świata przedstawionego, są elementy kulturowe. Jednakże zwłaszcza drugi rozdział omawianej historii, Co mówiła zakutana biegunica, może stanowić wyzwanie translatorskie ze względu na język literacki, cechujący się także obszernymi opisami. Natomiast w kolejnej historii czytelnikowi przedstawiona zostaje polska rodzina spędzająca wakacje w Chorwacji, podczas których główny bohater staje przed zadaniem poszukiwania nagle zaginionych żony oraz syna. Polskojęzyczni bohaterowie powieści determinują cechy językowe przedstawionego fragmentu, nacechowanego polskimi elementami kulturowymi takimi jak imiona czy związki frazeologiczne. Tragizm sytuacji przedstawionej implikuje również zastosowanie języka opisującego wiele nieoczywistych emocji, z których interpretacją mierzy się odbiorca, a także tłumacz.

\section{Autorskie działania tłumacza}

Tematem często analizowanym przez współczesnych badaczy przekładu jest rola tłumacza oraz stopień widoczności jego działań. Badania dotyczące tych zagadnień można znaleźć w pracach m.in. Anny Legeżyńskiej (1986), Jerzego Pieńkosa (1993), Lawrence’a Venutiego (1995) Magdaleny Mitury (2009) oraz Jerzego Brzozowskiego (2011). Można zauważyć, iż jedną z powszechnych taktyk przyjętych przez tłumaczy jest postawa bezpośredniego nieukazywania swoich działań w tłumaczonych tekstach (Pieńkos 1993, Mitura 2009). Według Lawrence'a Venutiego (1995: 1) oraz Moniki Linke (2008: 216-217) teksty takie spotykają się ze szczególną aprobatą ze strony odbior- 
ców. Również Carlos Casas w rozmowie z Zofią Zaleską (2015: 26) twierdzi, że „[d] obry przekład to taki, który po polsku brzmi bardzo naturalnie, tak jakby był to tekst autorski, stworzony w tym języku”. Niemniej jednak Venuti (1995: 1-5) podkreśla fakt, iż dzieła, w których działania tłumacza nie są bezpośrednio widoczne podczas lektury tekstu docelowego, w rzeczywistości podlegają szeregowi ingerencji translatorskich, do których zaliczyć można zastosowanie języka współczesnego, znanego odbiorcy, a jednocześnie niewskazującego na obce pochodzenie tekstu.

Legeżyńska (1986: 15, 33) zwraca jednak uwagę na fakt, iż działania translatorskie zawsze są w pewnym stopniu jawne, a stopień ich widoczności zależny jest od gatunku tekstu oraz jego cech. Podobny komentarz można znaleźć w pracy Elżbiety Tabakowskiej (2008: 504), która sugeruje, iż „[t]łumacz nieuchronnie zostawia po sobie ślady w każdym tłumaczonym tekście”. Na poparcie tej opinii można przytoczyć również słowa Michała Kłobukowskiego w wywiadzie z Zofią Zaleską (2015: 71), który twierdzi, iż w pracy tłumacza „nie da się wykluczyć elementu subiektywnego”. Natomiast Ireneusz Kania w rozmowie z tą samą autorką twierdzi, że głównym zadaniem tłumacza jest zbliżenie przekładu do dzieła pierwotnego, mimo tego, że zawsze będzie się on w pewien sposób różnił od oryginału (Zaleska 2015: 44). Ponadto czytelnik świadomy jest zazwyczaj obecności obu twórców, zarówno autora, jak i tłumacza dzieła, jednocześnie utożsamiając ich z różnymi funkcjami związanymi z tworzeniem tekstu (Legeżyńska 1986: 23-24).

Badania nad przykładami obecności oraz widoczności tłumacza znaleźć można w pracach Legeżyńskiej (1986) oraz Mitury (2009). Według badaczek pierwszy ślad jego obecności ujawnia się już na stronie tytułowej dzieła. Mitura (2009: 137) zwraca uwagę na informacje dotyczące autora oraz tłumacza, które poświadczają przekładowy charakter dzieła. Natomiast Legeżyńska (1986: 23) podkreśla strategię tłumaczenia tytułu, która implikuje dalsze zabiegi translatorskie. Kolejnym śladem wymienianym w obu pracach wskazującym na obecność tłumacza oraz obce pochodzenie dzieła jest występujące w tekście obce nazewnictwo związane z elementami kulturowymi, niemniej jednak badaczki zwracają uwagę, iż może ono występować również w tekście pierwotnym, a tym samym stanowić element obcości dla czytelników oryginału (Legeżyńska 1986: 13, Mitura 2009: 138-139). Ponadto opisane zjawisko może być również wynikiem błędu translatorskiego (Legeżyńska 1986: 13). Według Bożeny Tokarz (2003: 15) informacje dotyczące tłumacza oraz przyjętej przez niego strategii tłumaczenia „można odczytać z dokonywanych wyborów translatorskich na wszystkich poziomach tekstu". Tabakowska (2008: 505) zwraca również uwagę na fakt wpływu, jaki wywiera na tekst jego tłu- 
macz. Tak więc ślady tłumacza są widoczne już w lekturze samego przekładu, niemniej jednak pełen obraz jego działań można dostrzec dopiero, dysponując tekstem oryginalnym oraz jego tłumaczeniem, a także podczas ich analizy (Legeżyńska 1986: 22).

Badając autorskie działania tłumacza, Legeżyńska (1986: 38) zauważa pewien stopień podobieństwa procesu jego pracy oraz związanych z nim trudności do tych, z którymi mierzy się autor tekstu pierwotnego. W wyniku tego procesu na nowo kreowani są również bohaterowie, co umożliwia im funkcjonowanie w innych, obcych realiach językowych (Legeżyńska 1986: 17-18). Co więcej, można stwierdzić, że przetłumaczone dzieło jest w swojej kategorii tekstem oryginalnym (Legeżyńska 1986: 37). Szczególny problem związany z kwestią autorstwa pojawia się jednak w przypadku, gdy tłumacz decyduje się na wprowadzenie wielu korekt, których celem jest poprawa tekstu oryginalnego, a tym samym zapewnienie przekładowi lepszego odbioru w porównaniu do oryginału (Linke 2008: 212). Jednakże, jak zauważa badaczka, w tym przypadku wyłączne prawa autorskie nie mogą przypadać jedynie tłumaczowi lub jedynie autorowi, gdyż obaj mają znaczny wkład w powstanie nowego dzieła (Linke 2008: 212-213). Niemniej jednak, jak sugeruje Legeżyńska (1985: 32), „[w] perspektywie odbioru tłumacz jest »drugim autorem« tekstu wówczas, gdy jego obecność zostanie dostrzeżona przez czytelnika”.

Wielu badaczy zauważa również, iż wysiłki tłumaczy nie spotykają się z ogólnym docenianiem ich pracy przez odbiorców (Pieńkos 1993, Nida 1964, Zaleska 2015). Co więcej, Venuti (1995: 9) zwraca uwagę na to, iż głosem rozstrzygającym w kwestii przyznania autorstwa tłumaczowi mogą być kwestie prawne, w których za oryginalny uznaje się wyłącznie tekst pierwotny. Niemniej jednak, jak twierdzi Tabakowska (2008: 504), „[t]ak jak nie ma opowieści bez opowiadającego, tak też nie ma przekładu bez przekładającego, czyli tłumacza”. Również Legeżyńska (1986: 33) podkreśla ważną rolę tłumacza w przekładzie, a także fakt, że powstanie nowego dzieła nie byłoby możliwe ani bez wkładu autora, ani tłumacza.

\section{Strategie i techniki w tłumaczeniu literackim}

Pojęcie technik oraz strategii translatorskich jest kolejnym zagadnieniem pojawiającym się w licznych pracach podejmujących tematykę przekładu (Brzozowski 2011, Molina, Hurtado Albir 2002). Wielu badaczy zwraca jednak uwagę na pewną niejasność terminologiczną związaną z tymi kategoriami, podkreślając m.in. brak powtarzalnych oraz spójnych definicji (Piotrowska 
2002, Lewicki 2017, Hejwowski 2015). Przyjmując podział zaproponowany przez Lucię Molinę oraz Amparo Hurtado Albir (2002: 489-499, 507) można stwierdzić, że strategia jest narzędziem ogólnym, implikującym przebieg procesu translacji w związku z problemami z niego wynikającymi, natomiast technika znajduje zastosowanie jako konkretny środek translatorski w określonym segmencie tekstu.

Według Venutiego (2001: 240) dwa główne wyznaczniki strategii przyjętej przez tłumacza stanowią egzotyzacja oraz domestykacja. Domestykacja, jako prawdopodobnie najstarsza strategia, cechuje się dostosowaniem przekładu do cech kultury odbiorczej (Venuti 2001: 240-241). Zabieg ten wymaga od tłumacza wprowadzenia wielu zmian, których celem jest zastąpienie lub usunięcie elementów niejasnych oraz nieznanych jej nowym odbiorcom, tak aby tekst docelowy był bardziej zrozumiały (Mazi-Leskovar 2003: 254). Natomiast w przypadku egzotyzacji głównym celem przekładu nie jest ułatwienie odbioru, ale jak najdokładniejsze zilustrowanie realiów tekstu źródłowego, a także wprowadzenie czytelnika w świat obcej dla niego kultury (Mazi-Leskovar 2003: 254). Jak podkreśla Darja Mazi-Leskovar (2003: 254), zabieg ten może poprawiać funkcję estetyczną tekstu, czyniąc jego odbiór bardziej wymagającym, ale równocześnie ciekawszym. Autorka zwraca również uwagę na fakt, iż według współczesnych standardów translatorskich w przekładzie powinno się stosować zarówno strategię egzotyzacji, jak i domestykacji (Mazi-Leskovar 2003: 255).

Jeśli chodzi o techniki translatorskie, wielu badaczy zwraca uwagę na eksplicytację (Molina, Hurtado Albir 2002, Gumul 2006, 2017, Klaudy 2001). Jak podkreśla Ewa Gumul (2006: 19), jest ona jedną z technik przekładowych „stosowanych najczęściej po to, aby przekazać jak najdokładniej treść oraz intencje tekstu wyjściowego". Według Kingi Klaudy (2001: 80) oraz Lucii Moliny i Amparo Hurtdo Albir (2002: 500) w ramach tej techniki czytelnikowi podana zostaje informacja, która nie została przedstawiona bezpośrednio w tekście źródłowym, ale jednocześnie jest ona zrozumiała dla jego pierwotnych odbiorców. Jak podkreśla Klaudy (2001: 82-83), eksplicytacja może zostać wprowadzona na różnych poziomach tekstu, począwszy od zmian wynikających z cech gramatycznych oraz syntaktycznych danego języka, po elementy kulturowe, co do których wymaga się przedstawienia dodatkowych informacji. Jednak jak zauważa Gumul (2017: 28), zjawisko to związane jest z pewnym problemem, w wyniku którego bywa ono mylone na przykład $\mathrm{z}$ techniką dodania.

Według Moliny i Hurtado Albir (2002: 502) głównym celem wymienionej techniki dodania fragmentu tekstu, którą po raz pierwszy opisał Eugene 
A. Nida (1946), jest ułatwienie odbioru tłumaczenia jego nowym czytelnikom. Według Nidy (1964: 228) zabieg ten może wynikać m.in. z niejasnych struktur języka źródłowego lub ze zmian językowych wprowadzonych przez tłumacza. Ponadto technika ta może być wymagana w rezultacie zmian wprowadzonych w szyku zdania (Nida 1964: 230). Kolejną techniką, na którą zwraca uwagę wielu badaczy, jest opuszczenie fragmentu tekstu (Hejwowski 2015, Molina, Hurtado Albir 2002). Jednak jak zauważa Krzysztof Hejwowski (2015: 96-97), powinna być ona stosowana jedynie w sytuacjach wyjątkowych, gdy jej implementacja nie zaburzy przekazu. Dlatego też badacze podkreślają, iż opuszczenie stosowane jest zazwyczaj w przypadku informacji dodatkowych lub istniejących już implicite w tekście źródłowym (Hejwowski 2015, Molina, Hurtado Albir 2002).

Molina i Hurtado Albir (2002: 500) zwracają również uwagę na technikę adaptacji, którą można zdefiniować jako dostosowanie przedstawionych realiów kulturowych do kultury odbiorców. John Milton (2010: 3), odwołując się do Julie Sanders (2006), podkreśla mnogość różnic między oryginalnym tekstem a jego przekładem, które pojawią się w następstwie zastosowania wymienionej techniki. Badacz zwraca również uwagę na fakt, iż adaptacja może przybierać różne formy w zależności od gatunku tekstu, w którym została wprowadzona, ponadto technika ta może dotyczyć wielu jego aspektów. Tak więc technika adaptacji może przybierać formę zmiany fragmentu tekstu lub wprowadzenia nowych informacji, modyfikacji ulec może również język wypowiedzi bohaterów powieści (Milton 2010: 3-4).

Wielu badaczy zwraca również uwagę na zastosowanie przypisów oraz objaśnień (Hejwowski 2015, Nida 1964). Według Nidy głównym celem omawianej techniki jest ułatwienie odbioru przekazu jego obcojęzycznym czytelnikom. Może się ona odnosić więc do kwestii kulturowych lub gramatycznych (Nida 1964: 238-239). Hejwowski (2015: 97) zwraca również uwagę na inny aspekt tej techniki, który jest szczególnie ważny w przypadku omawianego w tym artykule przekładu, czyli na jej umiejscowienie: „[o]bjaśnienia można podzielić na jawne (objaśnienia w paratekście) i ukryte - wplecione w tekst przekładu bez informowania o tym czytelnika". Ponadto zabieg ten może dotyczyć wielu innych technik, gdyż, jak twierdzi badacz, „[w] szystkim [...] technikom może towarzyszyć objaśnienie, na przykład w formie przypisu" (Hejwowski 2015: 97).

Kolejną techniką, której uwagę poświęca wielu tłumaczy, jest dosłowne tłumaczenie tekstu (Molina, Hurtado Albir 2002, Kwieciński 2001, Newmark 1988). Według Moliny i Hurtado Albir (2002: 499) znajduje ono zastosowanie w przypadku braku różnic gramatycznych pomiędzy językiem oryginału 
oraz przekładu, co tym samym nie wymaga wprowadzania zmian. Niemniej jednak, jak podkreśla Newmark (1988: 68-69), technika ta nie zyskała powszechnego uznania w przekładoznawstwie, ponieważ oprócz zwolenników ma ona również wielu przeciwników.

\section{Analiza działań autorskich tłumaczki}

\subsection{Tytuł powieści}

Pierwszą autorską interwencję tłumacza zauważyć można już w tytule powieści. Oryginalne wydanie nosi tytuł Bieguni, natomiast w wersji anglojęzycznej tłumaczka zdecydowała się na rzeczownik Flights. Można zauważyć, że również polscy bieguni nie są dla rodzimego odbiorcy jednoznaczni, gdyż pewne wątpliwości może budzić zarówno etymologia, jak i semantyka tego wyrażenia. Wyjaśnienie tytułu znaleźć można na stronie internetowej komitetu noblowskiego w zakładce opisującej sylwetkę i dzieła noblistki w następujący sposób: „Tytuł pochodzi od nazwy dawnej rosyjskiej sekty gnostycznej, której członkowie wierzyli, że bycie w ciągłym ruchu zapobiega triumfowi zła" . Zauważyć można jednak, iż mimo pozornej niepolisemiczności polskiego wyrażenia bieguni, odnoszącego się do pradawnej sekty, Tokarczuk może sugerować przeniesienie jego znaczenia również na innych bohaterów powieści, których celem lub też fatum jest nieustanne przemieszczanie się, pozostawanie w ruchu fizycznym bądź symbolicznym w poszukiwaniu własnego ja. Ponadto tłumaczka w następujący sposób opisuje polski tytuł: „Słowo to w polszczyźnie jest dziwne - nieużywane przez mówiących tym językiem”2. Dlatego też można przypuszczać, że to właśnie niejasność tytułu dla rodzimych czytelników mogła ją skłonić do wprowadzenia zmian translatorskich. Można spekulować, iż tłumaczenie tytułu za pomocą strategii domestykacji lub egzotyzacji doprowadziłoby do trudności w jego odbiorze przez czytelników obcojęzycznych. Niemniej jednak pomimo jego zmiany Croft dąży do zachowania jego cech. Przede wszystkim zachowana została kategoria gra-

${ }^{1}$ Oryg.: , [t] $]$ he title is taken from the name of an old Russian, gnostic sect whose members believed that constant movement prevents the triumph of the evil demiurg" (https://www.nobelprize.org/prizes/literature/2018/bio-bibliography/, dostęp: 6.02.2020). Tłumaczenia cytatów wykonała autorka artykułu.

2 Oryg.: „The word in Polish is a strange one - not a word people use" (https://scroll.in/ article/882150/how-translator-jennifer-croft-won-ps26000-and-the-man-booker-internationalprize, dostęp 4.04.2020). 
matyczna - podobnie jak w oryginale został użyty rzeczownik. Jednocześnie poprzez powtórzenie formy jednowyrazowej tłumaczka, kontynuując zamysł autorki, unika ułatwienia czytelnikowi odbioru powieści bądź sugerowania jej interpretacji. Dlatego też biorąc pod uwagę cechy implicytne tytułu, zarówno Bieguni, jak i Flights, nie dają jednoznacznej podpowiedzi, która wskazywałaby na sposób odczytania treści powieści, pozwalając na jego indywidualną interpretację. Jednocześnie oba tytuły mają wymiar symboliczny, który nie ogranicza się do konkretnej postaci czy historii, ale w pewien sposób stanowi podsumowanie przesłania przekazanego czytelnikowi przez autorkę. Tytuł może być również postrzegany jako metaforyczna klamra spinająca losy wszystkich bohaterów i sytuacji przedstawionych w powieści.

\subsection{Interwencje autorskie niewpływające na stopień jawności tłumacza}

Tłumaczka decyduje się na kolejne interwencje autorskie w dalszej części powieści. Tak więc zaobserwować można konsekwencję działań translatorskich również w przypadku wystąpienia w tekście nazwy pradawnej sekty. Nazwa Flights pojawia się nie tylko $\mathrm{w}$ tytule powieści, ale również $\mathrm{w}$ tytule rozdziału, w polskiej wersji językowej - Bieguni. W przypadku wystąpienia nazwy sekty bądź jej członków w treści rozdziału tłumaczka, podobnie jak w tytule powieści, decyduje się na zastąpienie nazwy lub stosuje technikę ominięcia, co pozwala na uzyskanie koherentnego tekstu w języku docelowym. Zabieg ten jest doskonale widoczny między innymi w scenie zatrzymania Annuszki oraz towarzyszącej jest przedstawicielki sekty biegunów przez policję, gdzie czytelnikowi polskojęzycznemu przedstawiony zostaje następujący dialog:

Potem, gdy przychodzi ich kolej, czerwony policjant krzyczy przez ramię do kogoś w drugim pokoju:

- To ta biegunka.

A głos z tamtej strony mu odpowiada:

- Ją wypuść, ale spisz tę drugą, za zakłócanie.

Więc policjant mówi do zakutanej:

- Kobieto, następnym razem wywieziemy za miasto, sto kilometrów, rozumiesz? Sekciarzy tu nie chcemy (Tokarczuk 2007: 290).

W tłumaczeniu natomiast przynależność kobiety zostaje zastąpiona określeniem runaway woman (Tokarczuk 2018: 264), które w spójny sposób nawiązuje do zachowania kobiety, uciekającej nie tylko przed funkcjonariu- 
szami, ale również przed Annuszką. Cytowany fragment został przetłumaczony w następujący sposób:

Then, when their turn comes, the red-faced policeman shouts over his shoulder to someone in the other room:

'It's that runaway woman.'

The voice from in there answers:

'That one you can just let go, but write the other one up, for disturbing the peace.'

And to the shrouded woman the policeman says:

'Next time we're going to ship you out of town, a hundred kilometres out, got it? We don't want any cult members around here' (Tokarczuk 2018: 264-265).

Zauważyć można, iż w przytoczonym fragmencie powieści zachowany został fragment informujący czytelnika o istnieniu tajemniczej grupy ludzi, którzy mogą być wyznawcami sekty. Zabieg zastosowany w tłumaczeniu z pewnością miał wymiar celowy, gdyż w kolejnym rozdziale Tokarczuk zdecydowała się na wyjaśnienie czytelnikowi etymologii tytułu, prezentując obszerną historię powstania sekty biegunów, a także jej charakterystykę. Również tutaj dostrzec można kolejny ślad autorskiej ingerencji tłumaczki. Rozdział Co mówiła zakutana biegunica rozpoczyna opis filozofii sekty, którą tytułowa biegunica pragnie przekazać otaczającym ją przechodniom, a następnie autorka przechodzi do szczegółowego opisu powstania sekty biegunów, przytaczając historię „żołnierza o imieniu Eufemiusz” (Tokarczuk 2007: 292), którego można uznać za jej założyciela. W kolejnej części czytelnikowi przedstawiona zostaje etymologia nazwy:

Do owego świętego człowieka zaczęli dołączać inni ludzie, aż zebrało się ich multum, powstała wielka luźna grupa, a ci, którzy do niej przynależeli, rozpoznawali się po spojrzeniu, po drobnych gestach. I mimo że tworzyli wielką wspólnotę, nie rozróżniali wśród siebie ważniejszych i mniej ważnych, przywódców i poddanych, kaznodziei i słuchaczy. Wszyscy tutaj byli tacy sami - wieczni wędrowcy, którym nie wolno zatrzymać się choćby na chwilę i którzy nawet we śnie muszą się poruszać, a gdy zachorują, inni będą ich nosić, ażeby w bezruchu nie dopadł ich szatan. Widywano ich na drogach, traktach, gościńcach, konno i pieszo, na wozach i furmankach, aż zaczęto o nich mówić „bieguni”, od biegu, ucieczki. Z czasem można ich było spotkać w pociągach, autobusach, metrze, kolejkach, na statkach i w samolotach (Tokarczuk 2007: 292-293).

Croft zdecydowała się nie tylko na konsekwentnie omijanie nazwy pradawnej sekty, ale również na nieumieszczenie w przekładzie cytowanego 
akapitu. Można zauważyć, że polskojęzyczny fragment opisujący powstanie sekty cechuje się wieloma odniesieniami do zjawiska nieustannego ruchu, a tym samym do etymologii nazwy sekty. Dodatkowo Tokarczuk zdecydowała się na przywołanie nazwy, którą można określić jako głęboko zakorzenioną w kulturze słowiańskiej. Dlatego też chęć oddania w przekładzie tego akapitu prawdopodobnie wiązałaby się z umieszczeniem licznych przypisów, wyjaśniających nie tylko etymologię sekty biegunów, ale również wynikających z niej cech gramatycznych cytowanego akapitu, co mogłyby znacząco zaburzyć odbiór i zrozumienie powieści. Tak więc można stwierdzić, że konsekwentne działanie tłumaczki wynika $\mathrm{z}$ chęci utrzymania spójności tekstu oraz zbudowanego obrazu. Zabieg ten pozwala również na ominięcie elementów dodatkowych, niezrozumiałych dla społeczności nienależącej do kultury słowiańskiej. Jednakże oprócz ominięcia akapitu opisującego powstanie sekty biegunów można zauważyć kolejną znaczącą ingerencję autorską tłumaczki, jaką jest dodanie nowych fragmentów, niewystępujących w oryginalnej wersji językowej. Czytelnikowi anglojęzycznemu przedstawione zostają następujące akapity:

Whoever pauses will be petrified, whoever stops, pinned like an insect, his heart pierced by a wooden needle, his hands and feet drilled through and pinned into the threshold and ceiling.

This is precisely how he died, Yefim, he who rebelled. He was captured and his body nailed to the cross, immobilized like an insect, on display for human and inhuman eyes, but most of all inhuman eyes, which take the most delight in all such spectacles; hardly a surprise that they repeat them every year and celebrate, praying to the corpse $^{3}$ (Tokarczuk 2018: 267-268).

Autorskie akapity stworzone przez Croft są tak naprawdę kontynuacją historii Eufemiusza. Mimo iż omawiany fragment nie występuje w oryginalnej wersji powieści, jest on utrzymany w tej samej konwencji językowej, ponadto wprowadza elementy charakteryzujące sektę, którymi są potrzeba nieustannego poruszania się oraz uciekanie przed złem panującym nad świa-

3 „Ktokolwiek przystanie, zostanie sparaliżowany, ktokolwiek się zatrzyma, zostanie przygwożdżony niczym insekt, a serce jego przebite zostanie drewnianą igłą, a dłonie oraz stopy jego przewiercone oraz przygwożdżone do progu oraz sufitu. Właśnie w taki sposób zginął Eufemiusz, ten, który się zbuntował. Został schwytany, a ciało jego przygwożdżone do krzyża, unieruchomiony niczym insekt, wystawiony dla oczu ludzkich i nieludzkich. Jednak większość z wszystkich nieludzkich oczu, które najbardziej radują się z takich widowisk, była ogromnie zdziwiona, że powtarza się je co roku i świętuje, modląc się do ciała" (tłum. M. P.). 
tem. Tłumaczka w swym autorskim fragmencie opisuje również moment śmierci Eufemiusza, będącej rezultatem zatrzymania go i uchwycenia przez zło. Można zauważyć, że poprzez wprowadzenie nowego akapitu uzyskano efekt przekazania całości treści zawartej w tekście oryginalnym. Pomimo iż nazwa sekty nie występuje w tłumaczeniu ani razu, czytelnik nie został pozbawiony żadnych informacji czy też ukrytego sensu, który autorka powieści pragnie przekazać. Można również zauważyć, że liczne zmiany autorskie wprowadzone przez Croft nie wpływają na stopień jawności jej działań, dając złudzenie obcowania $\mathrm{z}$ tekstem oryginalnym. Również nowy akapit wprowadzony został w sposób nieujawniający ingerencji tłumaczki. W rezultacie zmiany te prawdopodobnie nie zostaną dostrzeżone nawet przez najbardziej uważnego czytelnika, dysponującego jedynie tekstem w języku docelowym, co można uznać za celowy zamysł tłumaczki, która pragnie oddać pierwszeństwo oryginalnemu tekstowi oraz jego autorce. Wszystkie ingerencje autorskie tłumaczki wprowadzone $\mathrm{w}$ obu omawianych rozdziałach dostrzegalne są jedynie podczas analizy dwutekstu, co jednocześnie nie wpływa na odbiór przekładu przez czytelnika obcojęzycznego.

\subsection{Interwencje autorskie a jawność tłumacza}

\subsubsection{Autorski komentarz tłumacza}

W swojej pracy tłumaczka decyduje się również na wprowadzenie szeregu wyjaśnień i komentarzy, szczególnie w przypadku pojawiających się w tekście elementów kulturowych. Przykład takich działań można zauważyć w rozdziale przedstawiającym historię polskiej rodziny Kunickich w momencie, gdy zrozpaczony mąż poszukuje w obcym kraju nagle zaginionych żony oraz syna. Tokarczuk przedstawia czytelnikowi następującą scenę:

Posuwają się cienistymi rzędami, wołając zaginioną kobietę: „Jagoda, Jagoda!”. Kunicki zdaje sobie sprawę ze znaczenia tego imienia, zapomniał już o tym, i nagle wydaje mu się, że bierze udział w pradawnym rytuale, zamazanym, groteskowym. Spod krzaków zwisają nabrzmiałe ciemnofioletowe grona, perwersyjne zwielokrotnione sutki, a on błądzi w liściastych labiryntach krzycząc: „Jagoda, Jagoda”. Do kogo to? Kogo szuka? (Tokarczuk 2007: 37)

Analizując cytowany fragment powieści, można stwierdzić, iż imię nadano bohaterce celowo. Oprócz jego homonimiczności, wykorzystanej do 
gry słów, imię to $\mathrm{w}$ połączeniu $\mathrm{z}$ sytuacją przedstawioną wskazuje również na dramatyzm momentu i bezsilność głównego bohatera. Można zauważyć, że wymienione czynniki stanowią wyzwanie translatorskie, gdyż należy zmierzyć się nie tylko z elementem kulturowym, jakim jest obce imię, ale także z ładunkiem emocjonalnym, który niesie przedstawiona sytuacja. Można stwierdzić, że próba domestykacji obcego imienia i zastąpienia go inną homonimiczną nazwą występującą w języku angielskim mogłaby nie oddać w tak jednoznaczny sposób dramatyzmu i metaforyczności sytuacji. Natomiast próba egzotyzacji, a tym samym pozostawienie nazwy w wersji polskiej, z pewnością wprowadziłaby element niejasności, zubażając obraz świata przedstawionego. Dlatego też w wydaniu anglojęzycznym czytelnikowi w następujący sposób zostaje przedstawione imię zaginionej kobiety:

'Jagoda, Jagoda!' It occurs to Kunicki that his wife's name means 'berry' in their native Polish. It is such a common name that he had forgotten about that until now ${ }^{4}$ (Tokarczuk 2018: 36).

Jak można zauważyć, tłumaczka postanowiła zachować imię kobiety w jego oryginalnej, polskiej formie, a następnie w języku docelowym wskazać na jego homonimiczny charakter oraz drugie, ukryte znaczenie. $\mathrm{W}$ ten sposób przekazana zostaje informacja niezawarta w tekście oryginalnym, lecz oczywista i zauważalna dla odbiorców polskojęzycznych. Dzięki temu autorskiemu zabiegowi translatorskiemu obie grupy odbiorcze dysponują taką samą wiedzą, co w pewnym stopniu umożliwia uzyskanie takiego samego efektu literackiego w przypadku oryginału oraz tłumaczenia. Niemniej jednak można zauważyć, iż Croft nie zdecydowała się na wytłumaczenie znaczenia imienia w przypisie, ale postanowiła włączyć je do opisu w taki sposób, aby czytelnik mógł ulec złudzeniu, że informacja ta istniała również $\mathrm{w}$ oryginale. Zabieg ten przede wszystkim nie zaburza spójności tekstu, a także pozwala czytelnikowi na pozostanie stricte $\mathrm{w}$ fabule powieści, bez potrzeby sięgania do przypisów. Co więcej, poprzez zastosowanie takiego komentarza tłumaczka nie ukrywa obcego pochodzenia tekstu ani umiejscowienia jego świata przedstawionego w obcych realiach.

Podobną autorską rolę tłumaczki można zauważyć również w przypadku pojawienia się w tekście słów chorwackich. Ponieważ zarówno język pol-

${ }^{4}$ „Jagoda, Jagoda! Kunicki zrozumiał nagle, że imię jego żony w języku polskim oznacza również owoc. Imię to jest tak popularne, że zupełnie o tym zapomniał, aż do tego momentu" (tłum. M. P.). 
ski, jak i chorwacki należą do grupy języków słowiańskich, można zakładać prawdopodobieństwo zrozumienia pojedynczych wyrazów przez osoby posługujące się tylko jednym $\mathrm{z}$ tych języków. Właśnie takie słowa zostały użyte przez Tokarczuk, prawdopodobnie celowo. Tak więc gdy w polskim tekście pojawiają się chorwackie słowa, np. „Powtarza dwa słowa "žena« $\mathrm{i}$ »dijete» - tylko to jest w stanie zrozumieć Kunicki” (Tokarczuk 2007: 38) lub „To je zato jer je po noči padala kiša - mówi ktoś po chorwacku i Kunicki dobrze rozumie, że chodzi o nocny deszcz" (Tokarczuk 2007: 44), polski czytelnik prawdopodobnie bez problemu domyśli się ich polskich odpowiedników. Niemniej jednak można przypuszczać, że takiej kompetencji językowej nie posiada większość odbiorców anglojęzycznych. Dlatego też Croft ponownie zdecydowała się na bezpośrednie dołączenie do tekstu autorskiego komentarza wprowadzającego czytelnika w realia języków słowiańskich.

W przypadku słów chorwackich zastosowane zostały dwie różne techniki. W pierwszej z nich słowa, które po polsku i chorwacku brzmią podobnie, przetłumaczone zostały na język angielski ze wskazaniem na ich fonetyczne podobieństwo do języka polskiego: „He repeats words 'wife' and 'child' in Croatian - those are the only words that sound enough like Polish for Kunicki to be able to understand"5 (Tokarczuk 2018: 36). Natomiast w przypadku drugiej techniki zachowane zostało zdanie oryginalne w języku chorwackim i dodano jedynie informację mówiącą o tym, iż w wyniku znajomości języka polskiego główny bohater mógł zrozumieć przekazaną informację: „parsing the Croatian through his own Polish"6 (Tokarczuk 2018: 44). Podobnie jak w przypadku wcześniej omawianego imienia tłumaczka konsekwentnie nie zdecydowała się na umieszczenie przypisu, ale tworząc koherentny obraz sytuacji przedstawionej, dołączyła swój autorski fragment do istniejącego tekstu. Zakładać można, że głównym celem Croft i tym razem nie było ułatwienie odbioru tekstu, ale wprowadzenie informacji, którymi odbiorca tłumaczenia z oczywistych powodów natury językowej nie może dysponować.

Można również zaobserwować, iż pomimo autorskich ingerencji Croft wprowadza nowy tekst w taki sposób, aby imitował on oryginał oraz nie sugerował wprost jej autorskich działań. Dlatego też można domniemywać, że unikanie bezpośredniego ujawnienia się $\mathrm{w}$ tłumaczonym tekście było jednym z czynników, który oprócz spójności wpłynął na decyzję tłumaczki o nieumieszczaniu przypisów. Niemniej jednak w przypadku omawianych

5 „Powtarza po chorwacku słowa »żona« i »dziecko« - są to jedyne słowa, które brzmią na tyle podobnie do polskiego, aby Kunicki był w stanie je zrozumieć” (tłum. M. P.).

6 „Tłumacząc chorwacki za pomocą polskiego” (tłum. M. P.). 
przykładów uważny czytelnik, świadomy języka oryginału oraz faktu, że przedstawieni bohaterowie posługują się językiem polskim, może zauważyć wprowadzone zmiany oraz pewien stopień jawności działań tłumacza. Zauważyć więc można, iż wraz z kolejnymi ingerencjami translatorskimi wzrasta stopień jego jawności w tekście.

Co więcej, zastosowanie techniki wyjaśniania polskich bądź chorwackich nazw umożliwia tłumaczce dalsze podobne ingerencje autorskie. Przykładem takiej modyfikacji może być fakt, iż nawet gdy Tokarczuk w oryginalnej wersji wprowadza dialog $\mathrm{w}$ języku polskim, tłumaczenie sugeruje czytelnikowi, że tak naprawdę rozmowa odbywa się w języku chorwackim. Zjawisko to ilustruje następujący przykład:

- Nie martw się - mówi bileter. - Tutaj nie ma jak się zgubić. Tutaj wszyscy jesteśmy widoczni jak na dłoni. - Tak mówi i pokazuje otwartą dłoń przeoraną kilkoma grubymi liniami. (Tokarczuk 2007: 58)

W tłumaczeniu cytowanego fragmentu zauważyć można nie tylko technikę eksplicytacji, przedstawiającą informacje zawarte w oryginale implicite, ale również autorskie modyfikacje tekstu docelowego:

'Don't worry', says the ticket seller. 'There is no way to lose somebody here.' He says something more and holds his hands out, fingers splayed, palm furrowed with thick lines, as Kunicki slowly translates his Croatian into Polish: 'We all stand out like sore thumbs', or something like it (Tokarczuk 2018: 55).

Można zauważyć, że początek wypowiedzi został przedstawiony w języku znanym odbiorcy, podobnie jak w przypadku oryginalnej wersji językowej. Jednak już w kolejnym zdaniu tłumaczka decyduje się na modyfikację tekstu, nie tłumacząc bezpośrednio dalszej wypowiedzi biletera, ale sugerując, że posługuje się on językiem obcym, który w stopniu ograniczonym jest zrozumiały dla głównego bohatera, tak więc ten zmuszony jest domyślać się wielu informacji przekazywanych mu przez rozmówcę. Informacja, która w tekście oryginalnym przedstawiona jest czytelnikowi w sposób bezpośredni, w tłumaczeniu wynika $\mathrm{z}$ interpretacji głównego bohatera oraz wprowadza

7 „- Nie martw się - mówi sprzedawca biletów. - Tutaj nie można nikogo zgubić. Dodaje coś jeszcze i wyciąga swoją pomarszczoną dłoń z rozłożonymi palcami, Kunicki wolno tłumaczy tę wypowiedź na polski jako: »tutaj wszyscy jesteśmy widoczni jak na dłoni« albo coś w tym stylu” (tłum. M. P.). 
sygnały obcości w tekście. Działanie tłumaczki widoczne jest również w przypadku związku frazeologicznego, wobec którego zastosowana została strategia domestykacji. Niemniej jednak ponieważ akcja opowiadania ma miejsce w Chorwacji, czytelnik polskojęzyczny również powinien być świadomy faktu, że rozmowy między bohaterami tak naprawdę nie mogą odbywać się $\mathrm{w}$ języku polskim. Zauważyć więc można, że w tym przypadku poprzez autorskie modyfikacje tłumaczka zdecydowała się na przedstawienie odbiorcy docelowemu informacji implicytnych dotyczących języka wypowiedzi oraz sytuacji przedstawionej, a także uwidoczniła trudności w porozumiewaniu się między bohaterami. Jednocześnie modyfikacje wprowadzają $\mathrm{w}$ tekście większy stopień obcości, nie zakłócając obrazu sytuacji przedstawionej, ale go dookreślając. Można się również zastanawiać nad stopniem jawności tłumacza w wyniku wprowadzonych zmian. Podobnie jak w przypadku wcześniejszych działań translatorskich tłumaczka nie pragnie całkowicie ich ukryć, lecz w sposób nienarzucający się pozwala na ich dostrzeżenie oraz interpretację.

\subsubsection{Działania autorskie wobec tekstu w języku angielskim}

Przeniesienie akcji powieści do kraju obcojęzycznego dla jego bohaterów daje autorowi możliwość przedstawienia dialogów również $\mathrm{w}$ innym języku niż ich język ojczysty. Dlatego też w przypadku opowiadania o rodzinie Kunickich oprócz języka chorwackiego, co wynika w sposób naturalny z usytuowania świata przedstawionego, pojawia się również współczesna lingua franca, czyli język angielski. Zabieg ten ilustruje następujący przykład: „Nie miała pieniędzy. No money. Wszystko jest tutaj” (Tokarczuk 2007: 42). Z przedstawionego cytatu odczytać można również fakt, iż bohaterowie posługują się tym językiem prawdopodobnie w stopniu komunikatywnym. W rezultacie ich wypowiedzi cechują się prostą składnią oraz budową jednozdaniową, często składają się z równoważników zdań lub pojedynczych słów. Dialogi w języku angielskim umieszczone w tekście polskim w sposób jednoznaczny wprowadzają sygnały obcości dla jego czytelników. Elementy te są kolejnym przykładem ilustrującym ingerencję autorską tłumaczki.

W tym przypadku tłumaczenie wyraźnie wyróżnia się przede wszystkim jasnym rozdzieleniem fragmentu wypowiedzi pojawiającego się $\mathrm{w}$ oryginale w języku polskim od fragmentu w języku angielskim, „'She didn't have any money', Kunicki says in Polish and then in English, 'No money. Here, everything"8

8 „- Nie miała żadnych pieniędzy - mówi Kunicki po polsku, a następnie dodaje po angielsku: - No money. Here, everything" (tłum. M. P.). 
(Tokarczuk 2018: 40). Dodana informacja ukazująca język wypowiedzi może być również odczytana jako świadome ujawnienie działań tłumaczki w sposób bardziej bezpośredni. W rezultacie pozwala ona na dostrzeżenie swojej ingerencji. Natomiast przetłumaczona fraza „Here, everything” pozbawiona czasownika być występującego $\mathrm{w}$ tekście oryginalnym, będąca równoważnikiem zdania, wyraźnie sugeruje stopień opanowania języka angielskiego przez głównego bohatera. Informacja dodana przez tłumaczkę pozwala na wprowadzenie sygnałów obcości, które w sposób naturalny występują w tekście oryginalnym. Ponadto zachowane zostały również pozostałe cechy wypowiedzi, takie jak lakoniczność oraz nierozbudowana składnia. Wprowadzone zabiegi pozwalają czytelnikowi obcojęzycznemu na zrozumienie sytuacji przedstawionej, jednocześnie nie zakłócając spójności wypowiedzi. Tak więc można sugerować, iż brak którejkolwiek ze zmian autorskich wprowadzonych przez Croft uniemożliwiłby odbiorcy docelowemu pełne przyswojenie przedstawionej sceny.

\section{Podsumowanie}

$\mathrm{Na}$ podstawie analizowanych fragmentów zauważyć można, iż tłumaczka zdecydowała się na wprowadzenie w swojej pracy wielu różnych zmian translatorskich za pomocą odmiennych technik. Zmiany te w sposób jednoznaczny łączą się ze stopniem jej jawności w przekładzie. Jednocześnie można zaobserwować pewną gradację jawności interwencji translatorskich, począwszy od zmian niezauważalnych dla czytelnika, po wyjaśnienia autorskie, które mogą zostać dostrzeżone przez uważnego odbiorcę świadomego pochodzenia oryginału. Jednocześnie poprzez wprowadzone zmiany tłumaczka nie dąży do bezpośredniej manifestacji swojej obecności w przekładzie, dlatego też między innymi nie decyduje się na zastosowanie przypisów. Tak więc można stwierdzić, że częściowe ujawnienie jej działań jest w tym przypadku pewnym narzędziem translatorskim pozwalającym na zachowanie spójności tekstu oraz umożliwiającym zrozumienie elementów osadzonych w ramach kulturowych. Można również zauważyć, że widoczność tłumacza implikowana jest cechami tłumaczenia literackiego, które umożliwia większą swobodę działań translatorskich. To właśnie przekład literacki pozwala tłumaczowi na jak największe spektrum działań, dając mu również kompetencje autorskie, jednak to od niego zależy, w jakiej skali zostaną one zrealizowane. Analizując powieść Bieguni, można również stwierdzić, że w przypadku tłumaczenia literackiego działania autorskie tłumacza nakierowane są na odbiorcę przekładu w taki sposób, aby tekst był jak najbardziej zrozumiały oraz ciekawy 
w odbiorze. Jednocześnie warto zauważyć, że w przypadku Biegunów tłumaczka nie pretenduje do uzyskania tytułu autorskiego ani do całkowitego ujawnienia swoich działań, ale pragnie pomóc autorce w przekazaniu treści eksplicytnych oraz implicytnych powieści.

\section{Źródła}

Tokarczuk O., 2007, Bieguni, Kraków.

Tokarczuk O., 2018, Flights, tłum. J. Croft, Croydon.

\section{Literatura}

Biobibliographical notes. NobelPrize.org. Nobel Media AB 2020. Thu 06 Feb 2020, https://www.nobelprize.org/prizes/literature/2018/bio-bibliography/ (dostęp: 6.02.2020).

Brzozowski J., 2011, Stanąć po stronie tłumacza. Zarys poetyki opisowej przekładu, Kraków.

Gumul E., 2006, Eksplicytacja a komunikatywność tekstu przekładu, [w:] Przekład jako komunikat, P. Fast, W. M. Osadnik (red.), Katowice-Warszawa-Częstochowa, s. 19-37.

Gumul E., 2017, Explicitation in simulatneous interpreting. A study into expliciting behaviour of trainee interpreters, Katowice.

Hejwowski K., 2015, Iluzja przekładu. Przekładoznawstwo w ujęciu konstruktywnym, Katowice.

How translator Jennifer Croft won $£ 26,000$ and the Man Booker International Prize, https://scroll.in/article/882150/how-translator-jennifercroft-won-ps26000-and-the-man-booker-international-prize (dostęp: 4.04.2020).

Klaudy K., 2001 [1998], Explicitation, [w:] Routledge encyclopedia of translation studies, M. Baker (red.), London-New York, s. 80-84.

Kwieciński P., 2001, Disturbing strangeness. Foreignization and domestication in translation procedures in the context of cultural asymmetry, Toruń.

Legeżyńska A., 1986, Tłumacz i jego kompetencje autorskie, Warszawa.

Lewicki R., 2017, Metody, techniki i strategie w procesie tłumaczeniowym. Próba uporządkowania terminologii przekładoznawczej, „Konińskie Studia Językowe", 5(3), s. 537-365. 
Linke M., 2008, A cognitive approach to equivalence in literary translation. Illustrated by an analysis of images of women in Henry James' „Portrait of a Lady” and its Polish translation „Portret Damy”, Toruń.

Mazi-Leskovar D., 2003, Domestication and foreignization in translating American prose for Slovenian children, „Meta. Translator's Journal”, 48(1-2), s. 250-265.

Milton J., 2010, Adaptation, [w:] Handbook of translation studies, t. 1, Y. Gambier, L. van Doorslaer (red.), Amsterdam-Philadelphia s. 3-6.

Mitura, M. 2009. Tłumacz czy autor? Vernon Sullivan bawi się (z) czytelnikiem, „Rocznik Przekładoznawczy. Studia nad teorią, praktyką i dydaktyką przekładu", 5, s. 133-144.

Molina L., Hurtado Albir A., 2002, Translation techniques revised. A dynamic and functionalis approach. „Meta. Translator's Journal”, 47(4), s. $498-512$.

Newmark P., 1988, A textbook of translation, New York.

Nida E. A., 1964, Toward a science of translating with special reference to principles and procedures involved in Bible translating, Ledien.

Pieńkos J., 1993, Przekład i tłumacz we współczesnym świecie, Warszawa.

Piotrowska M., 2002, A compensation model for strategies and techniques in teaching translation, Kraków.

Sanders J., 2006, Adaptation and appropriation, London.

Tabakowska E., 2008, Obecność tłumacza w tekście - spojrzenie językoznawcy, [w:] Oblicza Narcyza. Obecność autora w dziele, M. Cieśla-Korytowska, I. Puchalska, M. Siwiec (red.), Kraków, s. 503-518.

Tokarz B., 2003, Między psychologicznym a socjologicznym aspektem przekładu, [w:] Socjologiczne aspekty przekładu, P. Fast (red.), Katowice-Warszawa, s. 13-31.

Venuti L., 1995, The translator's invisibility. A history of translation, London-New York.

Venuti L., 2001 [1998], Strategies of translation, [w:] Routledge encyclopedia of translation studies, M. Baker (red.), London-New York, s. 240-244.

Zaleska Z., 2015, Przejęzyczenie. Rozmowy o przekładzie, Wołowiec. 


\section{Translator as an author on the basis of fragments of Flights by Olga Tokarczuk}

\section{Summary}

This paper aims to present the authorial role of the translator which he/she takes in the case of literary translation as demonstrated on the basis of chosen fragments of Flights, a novel by Olga Tokarczuk. Simultaneously, the paper focuses on the influence of the strategies and techniques implemented at the level of the translator's visibility. The paper begins with sections devoted to various studies connected with the topic of the translator's authorial role as well as the strategies and techniques that are frequently applied in the case of literary translation, whereas in subsequent sections examples of translator's operations in the text have been described.

It has been observed that the translator has implemented various modifications in the translated text. The first one is a change in the title of the novel. A less known name of the ancient sect has been substituted by a more modern form 'Flights'. Next, some shifts in the case of paragraphs could be observed. While the paragraph describing the etymology of the sect has been omitted, a new one has been created by the translator. Some other modifications are connected with authorial comments which the translator uses as a form of explanation of various culture-related words and phrases or sentences in the foreign language. It is worth noticing the fact that all comments have been incorporated into the text. Analysing the translation, it could be observed that the authorial modifications implemented are strictly related to the level of translator's visibility. Nevertheless, the translator never discloses her modifications directly, but rather allows readers to discern them by creating a coherent text. As a result, it could be observed that the level of the translator's visibility increases with authorial modifications. What is more, all alternations implemented in the translated text do not derange its understanding, but rather aim to present the information that the foreign reader is not able to possess. By her authorial role, the translator attempts to assist the author in conveying the entire and coherent message in the foreign language.

Keywords: translator, author, authorial role, modifications, translator's visibility 